\section{Vernalization Strategies to Enhance Production of Annual Globe Artichoke}

\author{
Anusuya Rangarajan, ${ }^{1}$ \\ Betsy A. Ingall, ${ }^{2}$ and \\ Victoria C. Zeppelin ${ }^{3}$
}

\begin{abstract}
Additional indeX words. Cynara
\end{abstract} scolymus, planting date

Summary. Annual production of globe artichokes (Cynara scolymus L.) requires vernalization of the plants, either through cold treatment of transplants or from natural tempera ture conditions in the spring. Studies were conducted in upstate N ew York, to determine if artificial vernalization treatments could be achieved by earlier planting dates. I nitial trials evaluated two varieties used for annual production in other parts of the country'I mperial Star' and 'G reen G lobe' I mproved. T ransplants were set in the field with or without a vernalizing cool treatment, to determine the extent of natural vernalization achieved under N ew York conditions. 'I mperial Star' produced slightly higher marketable yields than 'G reen G lobe I mproved' in 2 years of trials. Vernalization treatment increased the number of plants producing buds and the marketable yields, when transplants were set after $15 \mathrm{M}$ ay. $\mathrm{N}$ atural vernalization was achieved and cold treatment before transplanting did not improve yields of plants established in early May. At later planting dates, vernalizing transplants increased the number of plants producing apical buds (largest) by about $20 \%$ yet over $57 \%$ of

D epartment of Fruit and Vegetable Science, Cornell U niversity, I thaca NY 14853.

The cost of publishing this paper was defrayed in part by the payment of page charges. U nder postal regulations, this paper therefore must be hereby marked advertisement solely to indicate this fact.

This research was funded in part by USDA $\mathrm{H}$ atch Project 142406. Wegratefully acknowledgethecritical reviews by S. Reiners, K. Stewart and J. Sieczka.

${ }^{1}$ Assistant professor.

${ }^{2}$ Research technician.

${ }^{3}$ Former graduate research assistant. nonvernalized plants of each variety produced buds within the season. Average bud sizes did not vary with vernalization treatment. A similar number of days from transplanting to first bud harvest (69 to 75 days) was noted regardless of planting date and size of tran.

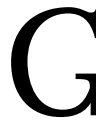

rowers in the northeast ern U nited States are continuously searching for potential new crops to diversify production and fill niche markets. Annually produced globe artichoke is one potential crop that can be grown in the northeastern U nited Statesand C anada using new varieties developed for annual production, such as 'I mperial Star' (IS) (Schrader and Mayberry, 1992) and 'Green Globe Improved' (GGI) (H ill and Maynard, 1989). Both of these varieties have been evaluated in other parts of the country and demonstrated production of high qualitybuds(Baggett et al., 1982; Bryant, 1993; H usain and Stewart, 1996; Welbaum, 1994;). Annual production requiresavernalization regime, in order to initiate the edible flower bud (capitulum) production ( $\mathrm{H}$ arwood and M arkarian, 1968). Imperial Star has been shown to have a lower vernalization requirement than GGI. After $205 \mathrm{~h}$ of lessthan $10{ }^{\circ} \mathrm{C}$ ( 50 ${ }^{\circ}$ ), $85 \%$ of IS plants produced buds, compared to $25 \%$ of GGI (Welbaum, 1994)

Vernalization has been induced in globe artichokes by stratifying seed (Gerakiset al., 1969; H ill and M aynard, 1989) or by exposing transplants to a cold treatment in a controlled environment or cold frame ( $\mathrm{H}$ ussain and Stewart, 1996). A viable alternative in the northeastern U nited States would be to establish transplants earlier in the spring when average temperatures are abovefreezing but lessthan $18.5^{\circ} \mathrm{C}$ (65 $\left.{ }^{\circ} \mathrm{F}\right)$, to achieve natural vernalization. Extended cold temperatures (less than $10{ }^{\circ} \mathrm{C}$ ) at too early a planting date, however, may slow plant establishment. Threeexperimentswith globeartichoke were conducted over 2 years (1997 and 1998) and at two locations in upstate $\mathrm{N}$ ew York ( $\mathrm{H}$ omer $\mathrm{C}$. Thompson Research Farm, Freeville, and E ast I thaca R esearch Farm, Ithaca). These studies explored yield differences by variety, efficacy of both natural and controlled vernalization techniques, and overall potential to produce artichokes in upstate N ew York.

\section{Materials and methods}

TranSPLANT PRODUCTION. D etailson artichokevariety, transplant production, and field establishment schedules for both years are provided in Table 1 . Seeds of IS (Santa M aria Seeds Inc., Santa M aria, Calif.) and GGI (PineT ree Garden Seeds, N ew G loucester, M aine) were sown in 128 -cell [25- $\mathrm{cm}^{3}$ (1.5inch $\left.{ }^{3}\right)$ ] plastic trays filled with a peatbased medium on 2 A pril 1997. After 3 weeks, plants were transplanted into $918-\mathrm{cm}^{3}\left(56-\mathrm{in}^{3}\right)$ pots [diameter $10 \mathrm{~cm}$ (4 inch) ] and grown for an additional 6 weeks. At transplanting, plants had an average of seven leaves, with a longest leaf length of $25 \mathrm{~cm}$ (10 inch). In 1998, IS seedswere sown on $18 \mathrm{M}$ arch and 24 $M$ arch, and for the variety trial, seeds of IS and G GI were sown on 8 A pril. After 3 weeks, these plants were transplanted to 50 -cell $\left[90-\mathrm{cm}^{3}\left(5.5\right.\right.$-inch $\left.\left.{ }^{3}\right)\right]$ trays. By using a smaller soil volume, transplants were smaller than those grown in 1997 and had an average of five leaves, but production time was reduced by 2 weeks. In both years, plants received $400 \mathrm{mg} \cdot \mathrm{L}^{-1}(\mathrm{ppm}) \mathrm{N}$ fertilizer on a weekly basis, using a formulation of $15 \mathrm{~N}-2.1 \mathrm{P}-12.5 \mathrm{~K}$. Plants were grown in a glass-covered greenhouse with supplemental overhead lighting (HID metal halide) to providea light intensity of 400 to $450 \mu \mathrm{mol} \cdot \mathrm{m}^{-2} \cdot \mathrm{s}^{-1}$ photosynthetic photon flux (PPF) for a $14 \mathrm{~h}$ photoperiod. Air temperatures were maintained at $24^{\circ} \mathrm{C}$ day/ $18.5^{\circ} \mathrm{C}(75 /$ $65^{\circ} \mathrm{F}$ ) night.

Vernalization. I $n$ both years, some transplantsreceived avernalization treatment just before field establishment (Table 1). A growth chamber (model GEL 511-38; Sherer-Gillett, M arshall, $\mathrm{M}$ ich.) with $13^{\circ} \mathrm{C}\left(55^{\circ} \mathrm{F}\right)$ day and night air temperatures and fluorescent light (300 to $350 \mu \mathrm{mol} \cdot \mathrm{m}^{-2} \cdot \mathrm{s}^{-1}$ PPF for 14 -h photoperiod) was used to supply the cool treatment. Transplants were maintained in thischamber for $19 \mathrm{~d}$ in 1997 , to ensure adequate cool temperature exposure for both varieties. In 1998, only $6 \mathrm{~d}$ of vernalization (same conditions as 1997) were used, due to the lower vernalization requirement for IS (Welbaum, 1994). Plants used in the 1998 variety trial were not vernalized.

FIELD ESTABLISHMENT, HARVESTING AND OVERWINTERING. The soil typeat E ast I thaca was an Arkport fine sandy loam (coarse-loamy, mixed, active, mesic Lamellic $\mathrm{H}$ apludalf) and at Freeville, a H oward gravelly loam (loamy-skeletal 
T able 1. Varieties, location of experiments and scheduling for transplant and field production of artichokes.

\begin{tabular}{|c|c|c|c|c|c|c|}
\hline Year & Varieties ${ }^{2}$ & L ocation ${ }^{y}$ & $\begin{array}{c}\text { Seeding } \\
\text { date }\end{array}$ & $\begin{array}{l}\text { Transplant } \\
\text { to larger } \\
\text { pot or } \\
\text { cell size }\end{array}$ & $\begin{array}{c}\text { Vernalization } \\
\text { treatments }\end{array}$ & $\begin{array}{c}\text { Transplant } \\
\text { to field }\end{array}$ \\
\hline 1997 & GGI, IS & El & $2 \mathrm{Apr}$. & 23 Apr. & None vs. $19 \mathrm{~d}$ at $13^{\circ} \mathrm{C}$ & 6 June \\
\hline \multirow[t]{2}{*}{1998} & IS & $\mathrm{EI}, \mathrm{FV}$ & $18 \mathrm{M}$ ar. & 17 Apr. & N one vs. $6 \mathrm{~d}$ at $13^{\circ} \mathrm{C}$ & 7 M ay \\
\hline & IS & $\mathrm{EI}, \mathrm{FV}$ & $24 \mathrm{M}$ ar. & $24 \mathrm{Apr}$. & $\mathrm{N}$ one vs. $6 \mathrm{~d}$ at $13^{\circ} \mathrm{C}$ & 15 M ay \\
\hline
\end{tabular}

${ }^{\mathrm{z}} \mathrm{GGI}=$ Green Globe I mproved, IS = I mperial Star.

y ocation of field experiments were $\mathrm{EI}=$ East I thaca or $\mathrm{FV}=$ Freeville.

xIn 1997, 3-week-old seedlings were transplanted to $918-\mathrm{cm}^{3}$ (56-inch $\left.{ }^{3}\right)$ pots. In 1998, same age seedlings were transplanted to 90 - $\mathrm{cm}^{3}$ (5.5-inch ${ }^{3}$ ) 50 -cell plastic trays.

mixed semic $\mathrm{G}$ lossoboric $\mathrm{H}$ apludalf). A portion of the fertilizer was broadcast and incorporated at each site before planting. In 1997, $106 \mathrm{~kg} \cdot \mathrm{ha}^{-1}(95 \mathrm{lb} /$ acre) of N , $24 \mathrm{~kg} \cdot \mathrm{ha}^{-1}(21 \mathrm{lb} /$ acre) of $\mathrm{P}$ $44 \mathrm{~kg} \cdot \mathrm{ha}^{-1}$ (39 lb/ acre) of $\mathrm{K}$ fertilizer wasapplied at East I thaca. In 1998, 112 $\mathrm{kg} \cdot \mathrm{ha}^{-1}$ (100 lb/ acre) of N , $25 \mathrm{~kg} \cdot \mathrm{ha}^{-1}$ (22 lb/ acre) of P, $46 \mathrm{~kg} \cdot \mathrm{ha}^{-1}(41 \mathrm{lb} /$ acre) of $K$ at East Ithaca and 102 $\mathrm{kg} \cdot \mathrm{ha}^{-1}(91 \mathrm{lb} / \mathrm{acre})$ of $\mathrm{N}, 45 \mathrm{~kg} \cdot \mathrm{ha}^{-1}$ (40 lb/ acre) of P, $85 \mathrm{~kg} \cdot \mathrm{ha}^{-1}(76 \mathrm{lb} /$ acre) of $K$ atF reevillewasapplied. Transplants were established on bare ground plotson J une6, 1997, using $0.6 \mathrm{~m}$ ( $2 \mathrm{ft}$ )

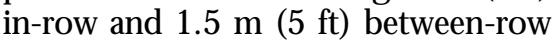
spacing, and 14 plants per plot. For 1998 plantings, raised bedswereformed ( $1.5 \mathrm{~m}, 5 \mathrm{ft}$ apart on center) and a single drip linewas buried [ $5 \mathrm{~cm}$ ( 2 inch) deep and off center of bed]. The bed was covered with a silver reflective mulch of $1 \mathrm{mil}$ [0.001 inch $(0.0254 \mathrm{~mm})$ ] thickness, Clark Agricultural Plastics, Va.) to reduce potential aphid infestations (observed in the 1997 trial). Plants were transplanted on two dates, 7 and 15 $M$ ay 1998 (Table 1). Plantswerespaced $0.6 \mathrm{~m}(2 \mathrm{ft})$ apart in rows, and therewere 12 plants/ plot. I rrigation was applied through a drip system in all studies. Additional nitrogen wasadded through the drip irrigation system during the growing season [1997, $67 \mathrm{~kg} \cdot \mathrm{ha}^{-1}(60$ $\mathrm{lb} /$ acre) of $\mathrm{N}$; 1998, $100 \mathrm{~kg} \cdot \mathrm{ha}^{-1}$ (89 $\mathrm{lb} / \mathrm{acre}$ ) of $\mathrm{N}$ at East I thaca and 84 $\mathrm{kg} \cdot \mathrm{ha}^{-1}(75 \mathrm{lb} / \mathrm{acre})$ of $\mathrm{N}$ at Freeville]. $\mathrm{N}$ o pesticides were applied in any of the experiments.

In 1997, buds were harvested, sorted and weighed based upon position on the flowering stalk- the primary being the terminal and the first and largest bud produced, secondaries being the next buds produced from axials below the terminal. In 1998, harvest methods were modified to sort buds according to California artichoke industry sizestandards(D eV os, 1992), and budswithin each classwereweighed. This change was made because artichoke buds are usually sold on a size basis. $M$ arketableartichokesweregraded according to four size classes; $18 \mathrm{~s}=18$ buds/ $22 \mathrm{lb}$ carton and larger than 4.5 inch $(114 \mathrm{~mm}), 24 \mathrm{~s}=4$ to $4.5 \mathrm{inch}$ ( 102 to $114 \mathrm{~mm}$ ) diameter, $36 \mathrm{~s}=3.5$ to 4 inch ( 89 to $102 \mathrm{~mm}$ ) diameter, and the rest bulked as $48 \mathrm{~s}=3$ to 3.5 inch ( 76 to $89 \mathrm{~mm}$ ) diameter.

In all three field trials, randomized complete block design was used, with three replications. Results for early and marketableyields, percent of plantsproducing primary buds (1997) and size distribution of all buds were analyzed for statistical differences among treatments.

In 1998, plantswereleft in thefield after the last harvest, to determine the potential for overwintering artichoke crowns. In early N ovember, tops were mowed within $15 \mathrm{~cm}$ ( 6 inch) of the soil surface, and crops mulched with $15 \mathrm{~cm}$ (6 inch) of straw. In M ay 1999, fields were evaluated and no surviving plants were found.

\section{Results and discussion}

Both IS and GGI produced high quality artichokes without any vernalizing treatments when grown in $\mathrm{New}$ York, over 2 years of experiments(T able 2 and 3). M arketable yield of IS was slightly higher in 1997 (Table 2) and significantly higher than GGI in 1998 (Table 3). These varieties varied in the number of plants producing buds, regardless of the vernalization treatment. An average of $86 \%$ of IS plants and $71 \%$ of GGI plants produced buds after an earlyJ uneplanting date(T able2). There was no difference in the average weight or thesize distribution of buds between thetwo varieties (T able 2 and 3), similar to results from previous evaluations of these two varieties (Welbaum, 1994).

D espite smaller size transplant and earlier planting date used in 1998, a similar number of days to first bud production was observed over both years; there were $69 \mathrm{~d}$ between transplanting and the first bud harvest in 1997 and 72 to 75 d in 1998, for both varieties. In trials in Q uebec, a similar daysto first harvest wasreported (H usain and Stewart, 1996), whereas in Virginia, first buds for both varieties were harvested after $91 \mathrm{~d}$ (Welbaum, 1994). $\mathrm{H}$ igher mean temperatures in Virginia may have contributed to the slower vernalization, potential devernalization of the plants when temperatures exceeded $32^{\circ} \mathrm{C}$, and a delay of bud harvest by $20 \mathrm{~d}$ compared to plants grown in N ew York (Gerakis et al., 1969). Bud quality under these higher temperatures could be compromised as well (Welbaum, 1994).

The effect of vernalization on artichoke yield varied by planting date. There were no interactions detected for varietyresponse(T able2). At later planting dates, such as early J une, vernalization treatment resulted in a $30 \%$ increase (significant difference) in thepercent of plants producing a primary bud, indicating that local temperatures in upstateN ew York werenot cool enough to induce flowering in all plants (T able 2). I mperial Star has a lower vernalization requirement than $\mathrm{GGI}$, contributing to the yield differences observed in the1997 trial (T able2). I n unvernalized plants, $74 \%$ of I S and $57 \%$ of GGI plants produced buds, in contrast to vernalized plants, for which $98 \%$ of I S and $86 \%$ of GGI produced buds (Table 2). In Virginia, an average of $55 \%$ of all plants produced buds after a mid-M ay planting date but none produced buds after a7J uneplanting date(Welbaum, 1994). $\checkmark$ ernal ization significantlyincreased the yield of primary and secondary buds after a June planting date, in 1997 (T able 2). $\mathrm{H}$ owever, after $\mathrm{M}$ ay planting dates in 1998 ( $T$ able 4), there was no 
T able 2. Marketable yield, average size, and size distribution of artichokes grown at E ast I thaca, N.Y., 1997.

\begin{tabular}{|c|c|c|c|c|c|c|c|}
\hline Treatment & $\begin{array}{l}\text { Early yield }{ }^{z} \\
\text { (g/plot) }{ }^{y}\end{array}$ & $\begin{array}{c}\text { M arketable } \\
\text { yield } \\
\text { (g/plot) }\end{array}$ & $\begin{array}{c}\text { Plants } \\
\text { producing } \\
\text { primaries } \\
(\%)\end{array}$ & $\begin{array}{c}\begin{array}{c}\text { Yield } \\
\text { of } \\
\text { primaries } \\
\text { (g/plot) }\end{array} \\
\end{array}$ & $\begin{array}{c}\text { Avg } \\
\text { primary } \\
\text { wt } \\
(\mathbf{g})^{\mathrm{w}}\end{array}$ & $\begin{array}{c}\begin{array}{c}\text { Yield } \\
\text { of } \\
\text { secondaries } \\
\text { (g/plot) }\end{array} \\
\end{array}$ & $\begin{array}{c}\text { Avg } \\
\text { secondary } \\
\text { wt } \\
(\text { g) } \\
\end{array}$ \\
\hline \multicolumn{8}{|l|}{ Variety } \\
\hline G reen Globe I mproved & 821 & 3079 & 71 & 798 & 160 & 2281 & 123 \\
\hline I mperial Star & 838 & 3455 & 86 & 1018 & 170 & 2437 & 129 \\
\hline \multicolumn{8}{|l|}{ Vernalization treatment } \\
\hline None & 477 & 2727 & 65 & 808 & 174 & 1920 & 140 \\
\hline Pretransplant & 1182 & 3806 & 92 & 1008 & 159 & 2798 & 121 \\
\hline \multicolumn{8}{|l|}{$\begin{array}{l}\text { Variety } \times \text { vernalization } \\
\quad \text { Vernalized }\end{array}$} \\
\hline Green Globe I mproved & 1025 & 3666 & 86 & 947 & 158 & 2719 & 117 \\
\hline Imperial Star & 1338 & 3947 & 98 & 1070 & 157 & 2877 & 119 \\
\hline \multicolumn{8}{|l|}{ U nvernalized } \\
\hline Green Globe I mproved & 616 & 2492 & 57 & 649 & 162 & 1843 & 98 \\
\hline Imperial Star & 337 & 2963 & 74 & 966 & 187 & 1997 & 146 \\
\hline \multicolumn{8}{|l|}{ M ain effects ${ }^{\vee}$} \\
\hline Variety & NS & NS & 0.05 & 0.05 & NS & NS & NS \\
\hline Vernalization & 0.05 & 0.05 & 0.01 & 0.05 & ns & 0.05 & 0.05 \\
\hline Variety $\times$ vernalization & NS & NS & NS & NS & NS & NS & NS \\
\hline
\end{tabular}

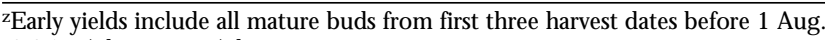

y $8.35 \mathrm{~g} / \mathrm{plot}=1 \mathrm{oz} /$ plot.

xprimary buds are terminal buds produced first in season, and are generally the largest produced by the plant. Secondaries develop from next axials of flower stalks.

w $28.35 \mathrm{~g}=1 \mathrm{oz}$.

$\mathrm{v}_{\mathrm{NS}}=$ nonsignificant; 0.05 , and 0.01 represent the level of statistical significance using the $\mathrm{F}$ test.

T able 3. E arly, total and marketable yield of artichokes grown in Freeville, N.Y., in 1998. T ransplants were not vernalized before field planting.

\begin{tabular}{|c|c|c|c|c|c|c|}
\hline \multirow[b]{2}{*}{ Cultivar } & \multicolumn{6}{|c|}{ Yield (g/plot) ${ }^{z}$} \\
\hline & Earlyy & T otal & M arketable & Size 18 & Size 24 & Size 36 \\
\hline Green G lobe Improved & 400 & 4767 & 3363 & 515 & 399 & 385 \\
\hline Significance of main effects ${ }^{w}$ & NS & NS & 0.05 & NS & 0.05 & NS \\
\hline
\end{tabular}

z28.35 g/ plot $=1 \mathrm{oz} /$ plot.

yE arly yields include all mature buds from first three harvest dates before $1 \mathrm{Aug}$

xBud size class description: $18=>4.5$ inches ( $114 \mathrm{~mm}$ ), $24=4.5$ to 4.0 inches (102 to $114 \mathrm{~mm}$ ), $36=4.0$ to $3.5 \mathrm{inches}$ ( 89 to $102 \mathrm{~mm}$ ).

$\mathrm{w}_{\mathrm{NS}}=$ nonsignificant; 0.05 , and 0.01 represent the level of statistical significance using the $\mathrm{F}$ test.

difference in overall bud size distribution (size classes) of vernalized compared to nonvernalized plants. All I S plants(vernalized and nonvernalized) produced budsin 1998 , indicating that natural vernalization wasachieved byearlier planting datescompared to the 1997 trial.

A significant interaction was detected between vernalization and planting date in 1998 (Table 4). For those plantsestablished at thesecond planting date (15 M ay), vernalization improved the marketable yield of bud production compared to the same treatment applied to the early planted crop (Fig. 1). D aily maximum air temperatures were considerably lower the week following the first transplant date ( $7 \mathrm{M}$ ay) compared to temperatures after the second date, at both F reeville [20 vs. $27^{\circ} \mathrm{C}(68$ vs. $\left.81^{\circ} \mathrm{F}\right)$ ] and East I thaca [20 vs. $26^{\circ} \mathrm{C}$
( 68 vs. $79^{\circ} \mathrm{F}$ )]. These warmer temperatures after the second plant date may havecontributed to lessuniform natural vernalization and bud production.

Vernalization increased early yield in 1997 by $60 \%$ (T able 2). T ransplanting by $6 \mathrm{M}$ ay increased early yields by $22 \%$ compared to the $15 \mathrm{M}$ ay planting, and vernalization of transplants significantly increased early bud production by $25 \%($ T able 4$)$. Thisdatasuggest that while vernalization may require special handling and additional expense to the grower, uniformity of primary bud production will be improved, even after early to mid $\mathrm{M}$ ay planting dates in upstateN ew York. Theinduction of earlier production also resulted in significantly more small artichokes (tertiary buds) to be produced later in the season (data not shown).
The significant differences in productivity were found between the two locations of trials. Early and marketable yields were higher at the East Ithaca location than at F reeville. The soil types at both locationswerewell drained; East I thaca was an Arkport fine sandy loam and at Freeville was a $\mathrm{H}$ oward gravely loam. An additional $34 \mathrm{~kg} \cdot \mathrm{ha}^{-1}(30 \mathrm{lb} /$ acre) of $\mathrm{N}$ was applied at E ast I thaca over the 1998 season. This additional nitrogen, however, would not be expected to contribute to this magnitude of yield increase (H usain and Stewart, 1996). M ean air temperaturesweresimilar across both locations [ $23{ }^{\circ} \mathrm{C}(73$ $\left.{ }^{\circ} \mathrm{F}\right)$ ], from J une through August, and similar to the previous 5 year average.

G rowers who are considering production of artichokes in the northeastern U nited Statesshould vernalizetrans- 
T able 4. E arly, total and marketable yield of artichokes grown in Freeville and E ast Ithaca, N.Y., in 1998.

\begin{tabular}{|c|c|c|c|c|c|}
\hline \multirow[b]{2}{*}{ T reatment } & \multicolumn{5}{|c|}{ Yield (g/plot) ${ }^{2}$} \\
\hline & Earlyy & Marketable & Size $18^{x}$ & Size 24 & Size 36 \\
\hline \multicolumn{6}{|l|}{ Location } \\
\hline Freeville & 1913 & 7505 & 227 & 1262 & 2894 \\
\hline East I thaca & 4312 & 9573 & 329 & 2541 & 3321 \\
\hline \multicolumn{6}{|l|}{ Vernalization } \\
\hline None & 2658 & 7906 & 347 & 2028 & 2780 \\
\hline Pretransplant & 3567 & 9172 & 209 & 1774 & 3436 \\
\hline \multicolumn{6}{|l|}{ Plant date } \\
\hline 6 M ay & 3501 & 8415 & 185 & 2086 & 2980 \\
\hline $14 \mathrm{M}$ ay & 2724 & 8663 & 371 & 1716 & 3234 \\
\hline \multicolumn{6}{|l|}{ Significance of main dffects ${ }^{w}$} \\
\hline Location & 0.01 & 0.05 & NS & 0.01 & NS \\
\hline Vernalization & 0.01 & NS & NS & NS & NS \\
\hline Plant date & 0.01 & NS & NS & NS & NS \\
\hline \multicolumn{6}{|l|}{ Interactions } \\
\hline Location $\times$ vernalizing & NS & NS & NS & NS & NS \\
\hline Location $\times$ plant date & NS & NS & NS & NS & NS \\
\hline Vernalizing $\times$ plant date & NS & 0.05 & NS & NS & NS \\
\hline Vernalizing $\times$ plant date $\times$ location & NS & NS & NS & NS & NS \\
\hline
\end{tabular}

$28.35 \mathrm{~g} /$ plot $=1 \mathrm{oz} /$ plot.

yE arly yields include all mature buds from first three harvest dates before $1 \mathrm{Aug}$.

xBud size class description: $18=>4.5$ inches ( $114 \mathrm{~mm}$ ), $24=4.5$ to 4.0 inches ( 102 to $114 \mathrm{~mm}$ ), $36=4.0$ to 3.5 inches ( 89 to $102 \mathrm{~mm}$ ).

$\mathrm{w}_{\mathrm{NS}}=$ nonsignificant; 0.05 , and 0.01 represent the level of statistical significance using the $\mathrm{F}$ test.

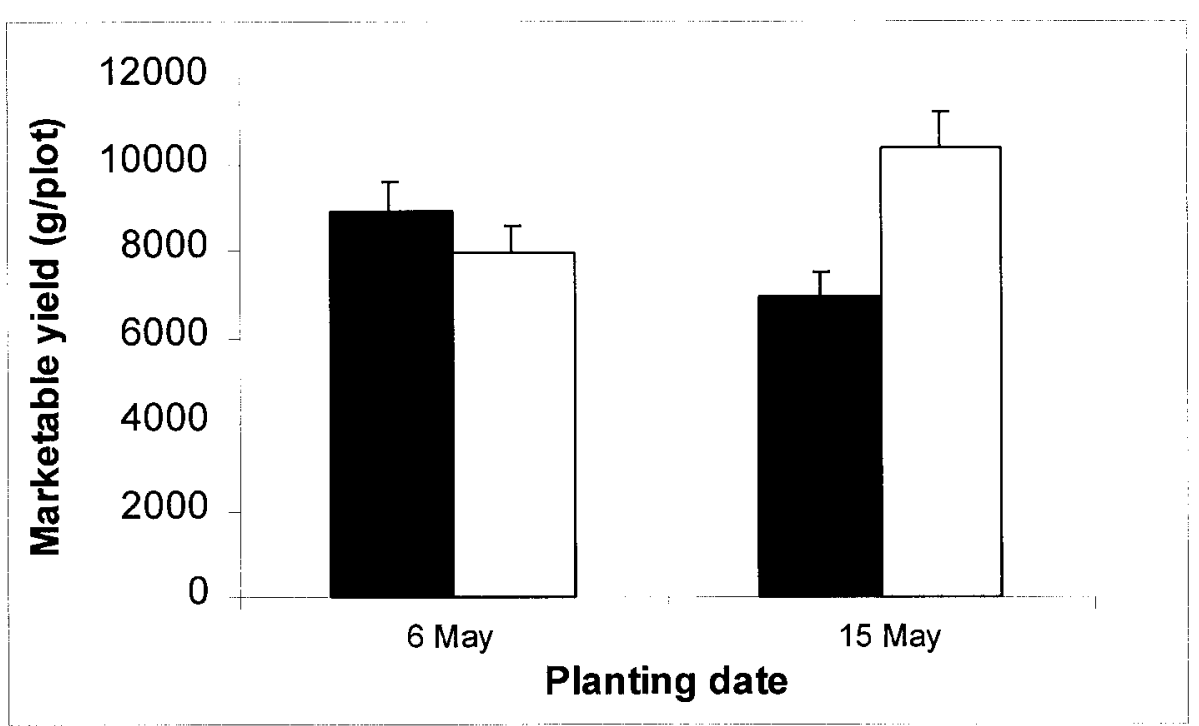

Fig. 1. I nfluence of vernalization treatment provided to artichokes planted on two dates in 1998. B lack bars represent marketable yield per plot from plants receiving no pretransplant vernalization treatments. White bars represent yield from plants receiving a vernalization treatment of $6 \mathrm{~d}$ of cool treatment in a growth chamber at $13^{\circ} \mathrm{C}\left(55^{\circ} \mathrm{F}\right)$ and $350 \mu \mathrm{mol} \mathrm{m}^{-2} \cdot \mathrm{s}^{-1}$ photosynthetic photon flux for $14 \mathrm{~h}$. Standard error bars for the means are provided. $28.35 \mathrm{~g} / \mathrm{plot}=$ $1.0 \mathrm{oz} / \mathrm{plot}$.

plantsif earlyuniform bud production is desired. This might be achieved either by use of a cold frame or cool greenhouse or by transplanting before 15 $M$ ay. Artichoketransplantsaresensitive to hard frosts, so some earlier planting dates may require use of row covers. To schedule production of both large and medium size buds over the season, later planting dates should also be consid- ered. In these cases, controlled vernalization of transplants would be recommended to ensure a high percentage of plants producing buds. Another strategy being tested is the application of gibberellic acid to induce bud formation in annual artichokes (Schrader, 1994). 'I mperial Star' produced higher marketableyields in 2 years of trials, when grown from vernalized or nonvernalized transplants, and isrecommended for usein the northeastern U nited States.

\section{Literature cited}

Baggett, J.R., H .J. M ack, and D. Kean. 1982. Annual culture of globe artichoke from seed. H ortScience 17:766-768.

Bryant, D. 1993. Seeds of Change: California artichoke growers are taking a close look at annual plantings to improve production timing and efficiency. Calif. Farmer 45:6-7.

De Vos, N.E. 1992. Artichoke production in California. H ortTechnology 2:438-444.

Gerakis, P.A., D. M arkarian, and S. Honma. 1969. Vernalization of globe artichoke, $C$ ynara scolymusL. J. Amer. Soc. H ort Sci. 94:254-258.

H arwood, R.R., and D. M arkarian. 1968. Annual culture of globeartichoke (C ynara scolymus L.). I. Preliminary R pt. Proc. Amer. Soc. H ort. Sci. 92:400-409.

H ill, D.E and A.A. M aynard. 1989. Globe artichoke trials 1987-1988. Conn. Agr. Expt. Sta. (M ay)867:3-9

H usain, S. and K. Stewart. 1996. Effects of nitrogen fertilizer rate and irrigation on the annual culture of globe artichoke in Q uebec. Proc. Annu. M tg. Amer. Soc. Plasticult. 197.

Schrader, W.L. 1994. Growth regulator gives earlier harvest in artichokes. Calif. Agr. 48(3): 29-32.

Schrader, W.L. and K.S. M ayberry. 1992. 'I mperial Star' artichoke. H ortScience 27:375-376.

Welbaum, G. 1994. Annual culture of globe artichoke from seed in Virginia. $\mathrm{H}$ ortT echnology 4:147-150. 